\title{
RECRUITMENT PERIODS OF TAGELUS DIVISUS (SPENGLER, 1794) (BIVALVIA; PSAMMOBIIDAE) IN THE PARANAGUÁ ESTUARINE COMPLEX - PR
}

\section{PERÍODOS DE RECRUTAMENTO DE TAGELUS DIVISUS (SPENGLER, 1794) (BIVALVIA; PSAMMOBIIDAE) NO COMPLEXO ESTUARINO DE PARANAGUÁ - PR}

\author{
Susete Wambier Christo ${ }^{1}$; Andréa Cancela da Cruz-Kaled ${ }^{2}$; Guisla Boehs ${ }^{3}$; \\ Theresinha Monteiro Absher²; Augusto Luiz Ferreira Junior ${ }^{4}$ \\ ${ }^{1}$ Correspondence autor. Universidade Estadual de Ponta Grossa - Departamento de \\ Biologia Geral. Email: <swchristo@hotmail.com> \\ ${ }^{2}$ Centro de Estudos do Mar/UFPR, Av Beira Mar s/n 83255-976 Pontal do Sul, PR, \\ Brazil. \\ ${ }^{3}$ Universidade Estadual de Santa Cruz. Rod. lhéus-Itabuna, km 16, 45.650-000 Ilhéus, \\ BA, Brazil. \\ ${ }^{4}$ Mestrando em Aquicultura. Universidade Federal de Santa Catarina.
}

\begin{abstract}
Tagelus divisus (SPENGLER, 1794) is a Psamobiidae bivalve of commercial value that inhabits shallow waters, buried in a sandy or sandy-muddy substratum. The present study analyzed the spatio-temporal distribution in an intertidal environment and some aspects of the population dynamics (recruitment) of that species in the Bay of Paranaguá (PR), for which two study places were established: St. I close to the access bars and St. II, in the medium section of the system, in which systematic collections were made, between abril/96 and outubro/97. Larger abundance of individuals was observed (juvenile) (p $<0,05$ ) in the more intern section of the estuary (St. II), of waters with mean salinity of 26 and of larger anthropic influence and, in the two places, preferential distribution in the higher tide levels, close to the Spartina belt. Larger recruitment rates were evidenced in the autumn and in the spring, following a reproductive pattern observed for several species of bivalve in the area.
\end{abstract}

Keywords: Settlement areas. Veneroida. Infaunal bivalves. Parana litoral.

\section{RESUMO}

Tagelus divisus (SPENGLER, 1794) é um bivalve psamobiídeo de interesse comercial que habita águas rasas, onde se enterra verticalmente no substrato arenoso ou arenolodoso. O presente estudo analisou a distribuição espaço-temporal em ambientes entremarés e alguns aspectos da dinâmica populacional (recrutamento) dessa espécie na Baía de Paranaguá (PR), para o qual foram estabelecidos dois locais de estudo: St. I, próximo às barras de acesso e St. II, no setor mediano do sistema, nos quais foram efetuadas coletas sistemáticas, entre abril/96 e outubro/97. Observou-se maior abundância de indivíduos (juvenis) $(\mathrm{p}<0,05)$ no setor mais interno do estuário (St. II), de águas com salinidade média de 26 e de maior influência antrópica e, nos dois locais, distribuição preferencial nos níveis de maré mais altos, próximo à faixa da gramínea Spartina. 
Maiores taxas de recrutamento foram evidenciados no outono e na primavera, seguindo um padrão reprodutivo observado para várias espécies de bivalves na região.

Palavras-chave: regiões de assentamento. Veneroida. bivalves infaunais. litoral paranaense.

\section{Introduction}

In spite of its economical importance as a food source to littoral populations, it has been little studied. Among the important resources for the sustainability of the coastal populations are the marine mollusks, that contribute with $31,8 \%$ of the biomass of cultivated and fished in the world (FAO, 2010). The bivalve from the family Psammobiidae (FLEMING, 1828) are resources frequently at several countries in the world (HOLLAND; DEAN, 1977; ROJAS et al., 1988; NISHIDA et al., 2004). Psammobiidae are bivalves with equal teliniform valves, 1 to 3 cardinal teeth and a deep palial sinus (RIOS, 2009). Tagelus divisus (SPENGLER, 1794) has a small thickened rib in the umbonal cavity, which is a diagnostic character of the species. It has ample distribution in the west Atlantic coast from North Caroline to Florida, Texas, West Indies, Venezuela and Brazil (Alagoas to Santa Catarina) in sandy and sand-silt bottoms of shallow waters (Rios, 2009). Adults (length over $20 \mathrm{~mm}$ ) occur buried 15 to $30 \mathrm{~cm}$ into the sediment vertically oriented (FRASER, 1967). At Paranaguá Bay estuarine complex studies with this specie are nonexistent. Our goal was to study the spatial (zonation) and temporal distribution of juveniles of $\underline{T}$. divisus in two intertidal flats of Paranaguá Bay and to analyze the recruitment of this species in the region.

\section{Material and Methods}

\section{Study Area}

The Paranaguá estuarine complex (PEC) is located in Paraná State $\left(25^{\circ} 30^{\prime} \mathrm{S} ; 48^{\circ} 25^{\prime} \mathrm{W}\right)$ and is part of an extensive subtropical estuarine system that includes Iguape-Cananéia Bay at the South coast of São Paulo State (LANA et al., 2000). The waters of the PEC are classified in three sectors (euhaline, polyhaline and mesohaline) based in the physicochemicals characteristics and the distribution of species (NETO, 1993). Noernberg et al., (2006) classified the region in five sectors considering the oceanographic and geographical characteristics, denominated as 1 -
Mixture; 2-Paranaguá; 3 - Antonina; 4 - Laranjeiras; 5 - Pinheiros (Fig.1). Average water temperatures varies from $20^{\circ} \mathrm{C}$ in winter to $30^{\circ} \mathrm{C}$ in summer, and a decreasing horizontal gradient of salinity is observed from the bay's entrance towards the inner sectors (KNOPPERS et al., 1987). The highest and smaller rainfall incidence occurs at summer and winter, respectively (PORTOBRÁS, 1988).

Two stations were sampled: Station I (St. I) located at the southeast side of Rasa da Cotinga Island (Lat. 25 33'S), near the bay's entrance (sector 1), and Station II (St. II) at its middle sector (Lat. $25^{\circ} 30^{\prime} \mathrm{S}$ ), near the port city of Paranaguá (sector 2; Fig. 1). Both sampling sites presented low declivity (St. I: 0.28 $\mathrm{cm} . \mathrm{m}^{-1}$ and St. II: $0.14 \mathrm{~cm} . \mathrm{m}^{-1}$ ), sandy-silty bottom with predominance of very fine sand in St. I $(\phi=3.1)$ and fine sand in St. II $(\phi=2.8)$, and mean salinity of 31 and 26, respectively (BOEHS et al., 2004).

Monthly samples were taken from April/1996 to October/1997. A $400 \mathrm{~m}$ long transect was established over the non-vegetated intertidal flat, between the Spartina alterniflora belt line and the emersion line at low spring tide, with 3 sampling levels (N1, N2 and N3). Samples with 10 random replicates at each level were collected with a corer $\left(\right.$ area $\left.=0.049 \mathrm{~m}^{2}\right)$ buried $10 \mathrm{~cm}$ in the sediment, and sieved through a $1 \mathrm{~mm}$ mesh size net. The specimens were quantified and the antero-posterior (length - L) line measured. Frequency of occurrence was obtained through the Constancy Indices (BODENHEIMER, 1955):

$$
C=\frac{P}{N} \times 100
$$

where $C=$ constancy indices, $P=$ number of samples containing the species, $N=$ total number of samples.

For the characterization of the recruitment periods of $\underline{T}$. divisus juveniles an analysis of the absolute frequency was made in relation to the temporal variation of the points studied in the intertidal plains of the Estuarine Complex of Paranaguá.

Density as individuals.m ${ }^{-2}$ was compared between locals, sampling levels and during the period 
sampled by means of unifatorial ANOVA $(\alpha=0.05)$. Least Significant Difference (LSD) test was used to verify significant differences a posteriori.

\section{Results}

Tagelus divisus frequency of occurrence was higher than 50\% (St. I: $67 \%$; St. II: $89 \%$ ), and thus classified as a constant species in both environments. However, in spite of great fluctuation in both populations during the period, densities at the middle sector (St. II), were significantly higher $(\mathrm{p}<0.05)$ than at the bay's entrance (St. I), with 243 individuals (average: 19.1 \pm 16.1 inds. $\mathrm{m}^{-2}$ ) and 32 individuals (average: $1.86 \pm 1.84$ inds. $\mathrm{m}^{-2}$ ), respectively (Fig. 2 e 3 ).

Juveniles and recruits were more abundant at the highest level (N1) in both flats. At St. II, this zonation resulted in a statistically significant difference $(\mathrm{p}<0.05)$ among levels. LSD indicated $\mathrm{N} 1>\mathrm{N} 2=\mathrm{N} 3$ (Fig. 2 e 3 ).

The size of the juvenile populations, throughout the studied period, showed a significant increase $(p<0.05)$ in the winter for St. I and winter and summer for St. II (Fig. 4).

This was probably due to settling in the previous fall and spring. Despite the small sample size at St. I $(\mathrm{N}=32)$, a progressive mode starting in June/1996 is observed and showed that this cohort resulted from the fall recruitment (March/April). Recruits $(\mathrm{L} \leq 3 \mathrm{~mm})$ were sampled at this location in the fall of the following year (May/1997). At St. II, a similar situation was observed with a progression of successive modes resulting from fall and spring recruitment, with a consequent increase in the size of the population during the following seasons. That the adult size $(\mathrm{L}=20 \mathrm{~mm})$ is attained in a short period of time (7-8 months) (Tab. 1).

\section{Discussion}

The distribution of benthic fauna throughout bays and estuaries is mainly conditioned by hydrographic factors and by sediment characteristics. Salinity variations throughout these systems were reported as determinants of the occurrence and the relative abundance of species (TOMMASI, 1970; STUARDO; VILLARROEL， 1976; CAPITOLI et al., 1978; WU; RICHARDS, 1981). Rojas et al.
(1988) working with Tagelus peruvianu s in two sectors (superior and inferior) of a beach in the city of Putarenas - Costa Rica, identified a variation of salinity from 0 to 33 . Some Psammobiidae like Tagelus plebeius (LIGHTFOOT, 1786) are reported as being typically estuarine species (TOMMASI 1970; RIOS, 2009), well adapted to less saline waters. In the environments studied in the present work, Boehs et al. (2004) observed the occurrence of this species only at St. II, where the mean salinity is 26 . Our results showed that $\underline{\mathrm{T}}$. divisus is adapted to a greater amplitude of salinity variation, since it occurred at both locations. However, considering the fact of its lower abundance at St. I, where the mean salinity is 31 (BOEHS et al. 2004), we may presume that the conditions at these environment are less favorable (even though not excluding) to the species establishment if compared to St. II.

Anthropogenic activities near St. II, originated from the city and port of Paranaguá, like of fertilizer and grain, and discharge of wastewaters from the port and the city, most likely influences the structure of nearby benthic communities by the increasing availability of the local organic matter. The presence of a greater number of juveniles and recruits at the highest level of the intertidal zone may indicate the occurrence of a preferential level for settlement. Boehs et al. (2004) also observed this kind of distribution for others Veneroida like T. plebeius, Lucina pectinata (GMELIN, 1791) and Anomalocardia brasiliana (GMELIN, 1791). Probably, recruits find better protection against predation and more available space for settlement at this location, since the faunal density at this level is lower than the ones at the level nearest to the permanently submerged area. This most likely increases the chances for survival and success in the recruitment The fact that individuals reached $20 \mathrm{~mm}$ in 7-8 months (according to size frequency) and due to the sampling schedule (18 months), adults should have been present in the samples, unless others events as mortality occurred. Except for this last possibility, the lack of those individuals in the samples was most probably influenced by the sampling design. According to Fraser (1967), adults occupy preferably levels of 15 and $30 \mathrm{~cm}$ in the sediment. Since samples were taken from depths of $10 \mathrm{~cm}$, it is possible that the adults were out of the reach of the sampling gear. Fraser (1967) related this size segregation to be due 
to a greater capacity of the adults to move andthus occupy deeper layers in the sediment. Another possibility for the lack of individuals bigger than 20 $\mathrm{mm}$ in the samples might be due to the population dynamics of $\underline{T}$. divisus in the region where bigger individuals migrate to lower levels, permanently submerged.

For T. peruvianus in Costa Rica, Rojas et al. (1988) verified a spawning relatively continuous with larger predominance of maturation during the months of November and December resulting in a massive spawning during the months of January and February and thus allowing a recruitment in the month of March. Fraser (1967) working with $\underline{T}$. divisus in the USA identified a larger maturation during the month of November, with subsequent spawning in the months of December and January and a recruitment during the month of June. This same author reports that this is possible due to the fast growth during the first year of life of this species in the area. Similar results were found in this work for the recruitment period, where it was possible to verify the presence of smaller cohorts in the months of June of 1996 and May of 1997 for station I and in the months of August of 1996, March and June of 1997 for station II.

Rojas et al. (1988) identified densities of $\underline{T}$. peruvianus in two sectors of the beach (upper level: 53,96 individuals $/ \mathrm{m}^{2}$; lower level: 71,40 individuals/ $\mathrm{m}^{2}$ ), with a larger density of juvenile organisms in the inferior part. Those authors discuss that these characteristics may be associated to a larger recruitment of the organisms or a larger impact of the exploration of the species on the juveniles in the superior section of the beach, because that local stays for longer time emerged and consequently more accessible to exploration. For T. divisus Denadai et al. (2000) in a characterization of the mollusks fauna of two beaches in São Sebastião's channel, Brazil, identified a density of 0,22 and 1,40 individuals $/ \mathrm{m}^{2}$ at $10 \mathrm{~cm}$ of depth. Fraser (1967) in studies of the

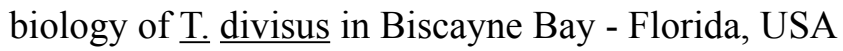
using Van Veen and Paterson types bottom dredges collected organisms that varied from 0,3 to $2,5 \mathrm{~cm}$. These same authors reports that this sampling method is inadequate for studies of characterization of the population of $\underline{T}$. divisus, because only the juveniles stay in the superficial layer of sediment (adults stays preferentially in the depth from 15 to $30 \mathrm{~cm}$ of sediment), due to the smaller length of the shell and size of the siphon in relation to the adults. Such results coincide with the ones found in this work, because it was identified the predominance of organisms up to $23 \mathrm{~mm}$ in length at a depth of $10 \mathrm{~cm}$ of the sediment.

Similarly to what is observed for other bivalves in the region, as $\underline{\text { A }}$ brasiliana (BOEHS, 2000) and oysters of the genus Crassostrea (SILVABOEHS; ABSHER, 1996), T. divisus seems to have a continuous reproduction, with two annual peaks of recruitment, one in spring and another in fall, what seems to be a pattern for subtropical regions. According to Giese \& Pearse (1974), continuous reproductive effort occurs in the absence of a selective influence determined by some exogenous factors that favors the reproduction in certain periods of the year. This type of reproduction is common in those marine invertebrates from ecosystems of greater environmentalstability, as deep sea and subtropical areas. Temperature was recorded as the most important exogenous factor in regulating the reproductive phenomenon of marine mollusks since, together with salinity, it determines the qualitative and quantitative planktonic composition favoring the nutritional demands of those organisms (MACKIE, 1984). It also acts upon the transfer of reserves stocked in the digestive gland to the gonads, that are sequentially used for the gametogenesis process (LOOSANOFF; DAVIS, 1952). At Paranaguá Bay, the increase in temperature from the beginning of spring and during summer most likely stimulates the process of gamete formation and maturation in bivalves, reaching massive gamete elimination at the end of spring and again at the end of summer. These phenomen result in the occurrence of great recruitment peaks at the end of spring (October-November) and in the beginning of fall (March-April). Boehs (2000) observed in $\underline{A}$. brasiliana, that a greater success in the juveniles development occurs at fall recruitments, compared to ones at spring. The same trend was observed by the modal progressions obtained for $\underline{T}$. divisus in the present work. This fact may be attributed to higher mortality rates during summer mainly due to an increase of predation pressure in sandbanks by macropredators and/or by physiological stress caused by abrupt salinity variation resulting from intense summer rains. From the analysis of size frequency distribution we may conclude that $\underline{T}$. divisus has a 
rapid growth and once reaching $20 \mathrm{~mm}$ of length at 7-8 months (size reported by Fraser, 1967 as being of the adult), a fall (or spring) recruit would be able to contribute to the reproductive input of the population in the following reproductive pulse. However, additional histology studies of the gonads in various reproductive phases should be done to confirm this hypothesis.

\section{Conclusion}

Larger abundance of individuals was observed in the more intern section of the estuary, with larger anthropic influence. Larger recruitment of the $\underline{T}$. divisus was evidenced in the autumn and in the spring.

\section{REFERENCES}

BOEHS, G. Ecologia populacional, reprodução e contribuição em biomassa de Anomalocardia brasiliana (Gmelin, 1791) (Bivalvia: Veneridae) na Baía de Paranaguá, Paraná, Brasil. 201p. Tese (Doutorado) Universidade Federal do Paraná, Curitiba, Brasil, 2000.

BOEHS, G.; ABSHER T. M.; CRUZ-KALED A. Composition and distribution of benthic molluscs on interdital flats of Paranaguá Bay (Paraná, Brazil). Scientia Marina, v.68, n.4: p.537-543, 2004.

CAPITOLI, R. R.; BEMVENUTI, C. E.; GIANUCA, N. M. Estudos de ecologia bentônica na região estuarial da Lagoa dos Patos. I-As comunidades bentônicas. Atlântica, v.3, p.5-22, 1978.

DENADAI, M. R.; AMARAL, C. Z.; TURRA, A. Annual variation of the malacofauna on two intertidal sandy substrates with rock fragments in southeastern Brazil. Revista Brasileira de Oceanografia, v.48, n.2, p.141-150, 2000 .

FAO - FOOD AND AGRICULTURE ORGANIZATION OF THE UNITED NATIONS 2010. The State of world fisheries and aquaculture (Sofia). Roma, 2010. Disponível em: <http://www.fao.org/docrep/013/i1820e/i1820e00. htm>.

FRASER, T. H. Contributions to the biology of Tagelus divisus (Tellinacea:Pelecypoda) in Biscayne Bay, Florida. Bull. Mar. Sci., v.17, n.1, p.111-132, 1967.

HOLLAND, A. F.; DEAN J. M., The biology of the stout razor clam Tagelus plebeius: I. Animal-sediment relationships, feeding mechanism, and community biology. Chesapeake Science, v.18, p.58-66, 1977.

GIESE, A. C.; PEARSE, J. S. Introduction: General Principles. In: GIESE, A. C.; PEARSE, J. S. (Ed.).
Reproduction of marine Invertebrates. New York: Academic Press, 1974. v.1, p.1-49.

KNOPPERS, B. A.; BRANDINI, F. P.; THAMM, C. A. Ecological studies in the Bay of Paranaguá. II. Some physical and chemical characteristics. Nerítica, v.2, n.1, p. 1-36, 1987.

LANA, P. C.; MARONE, E.; LOPES, R. M.; MACHADO, E. C. The subtropical estuarine complex of Paranaguá Bay, Brazil. In: SEELIGER, U.; LACERDA, L.; KJERFVE, B. (Ed.) Coastal marine ecosystems of Latin America. Berlin: Springer Verlag, 2000. p.131-145

LOOSANOFF, V. L.; DAVIS, H. C. Temperature requirements for maturation of gonads of northern oysters. Bol. Bull., v.103, n.1, p.80-96, 1952.

NETO, S. A. Composição, distribuição e variabilidade sazonal da macrofauna bêntica de marismas e bancos não-vegetados da Baía de Paranaguá (Paraná, Brasil). Dissertação (Mestrado) - Curso de Pós-graduação em Zoologia, Departamento de Ciências Biológicas, Universidade Federal do Paraná, Curitiba, 91 p. 1993.

NISHIDA, A. K.; NORDI, N.; ALVES, R. R. N. Abordagem e etnoecológica da coleta de moluscos no litoral paraibano. Tropical Oceanography, Recife: v. 32, n. 1, p. 53-68, 2004.

NOERNBERG, M. A.; LAUTERT, L. F. C.; ARAÚJO, A. D.; MARONE, E.; ANGELOTTI, R.; NETTO Jr, J. P. B.; KRUG, L. A. Remote sensing and GIS integration for modelling the Paranaguá estuarine complex Brazil. Journal of Coastal Research, SI 39, Itajaí, SC, Brazil, p.16271631, 2006.

MACKIE, G. L. Reproduction. In: WILBUR, K. M. (Ed.) The mollusca. Orlando: Academic Press, Inc., v. 7. p.351418, 1984.

PORTOBRÁS- Empresa de Portos do Brasil S.A. Relatório de apresentação das medições metereológicas observadas em Pontal do Sul, Paranaguá-PR. Período set.1982 a dez.1986. Rio de Janeiro, Inst. Pesq. Hidr. (INPH), 1988.

RIOS, E. C. Compendium of brazilian sea Shell. Rio Grande, RS. FURG, 2009, 676p.

ROJAS, J.; VILLALOBOS, C. E.; CHARTIER, F.; VILLALOBOS, C. R. Tamaño, densidad y reproducción de la barba de hacha, Tagelus peruvianus (Bivalvia: Solecurtidae) em el estero de Puntarenas, Costa Rica. Revista de Biologia Tropical, v.36, n.2B, p.479-483, 1988.

SILVA-BOEHS, G.; ABSHER, T. M. Variação temporal de larvas de ostras do gênero Crassostrea Sacco, 1897 (Ostreoida:Ostreidae) na Baía de Paranaguá, Paraná (Lat.2516'34”S; Long. 48 17'42”W). Arq. Biol. Tecnol. v.39, n.4, p. 903-910, 1996.

STUARDO, J.; VILLARROEL, M. Aspectos ecologicos $\mathrm{y}$ distribuicion de los moluscos en las lagunas costeras 
de Guerrero, Mexico. An. Centro Cienc. Del Mar y Limnología, Univ.Nac.Auton.Mex., v.3, n.1, p. 65-91, 1976.

TOMMASI, L. R. Observações sôbre a fauna bêntica do Complexo Estuarino-Lagunar de Cananéia (SP). Bol. Inst. Oceanogr., São Paulo v.19, p.43-56, 1970.
WU, R. S. S.; RICHARDS, J. Variations in benthic community structure in a sub-tropical estuary. Marine Biology, v.64, p.191-198, 1981.

\section{Figures}

Figure 1- Paranaguá estuarine complex (PEC) with the sampling locations. •: Station I and a: Station II.

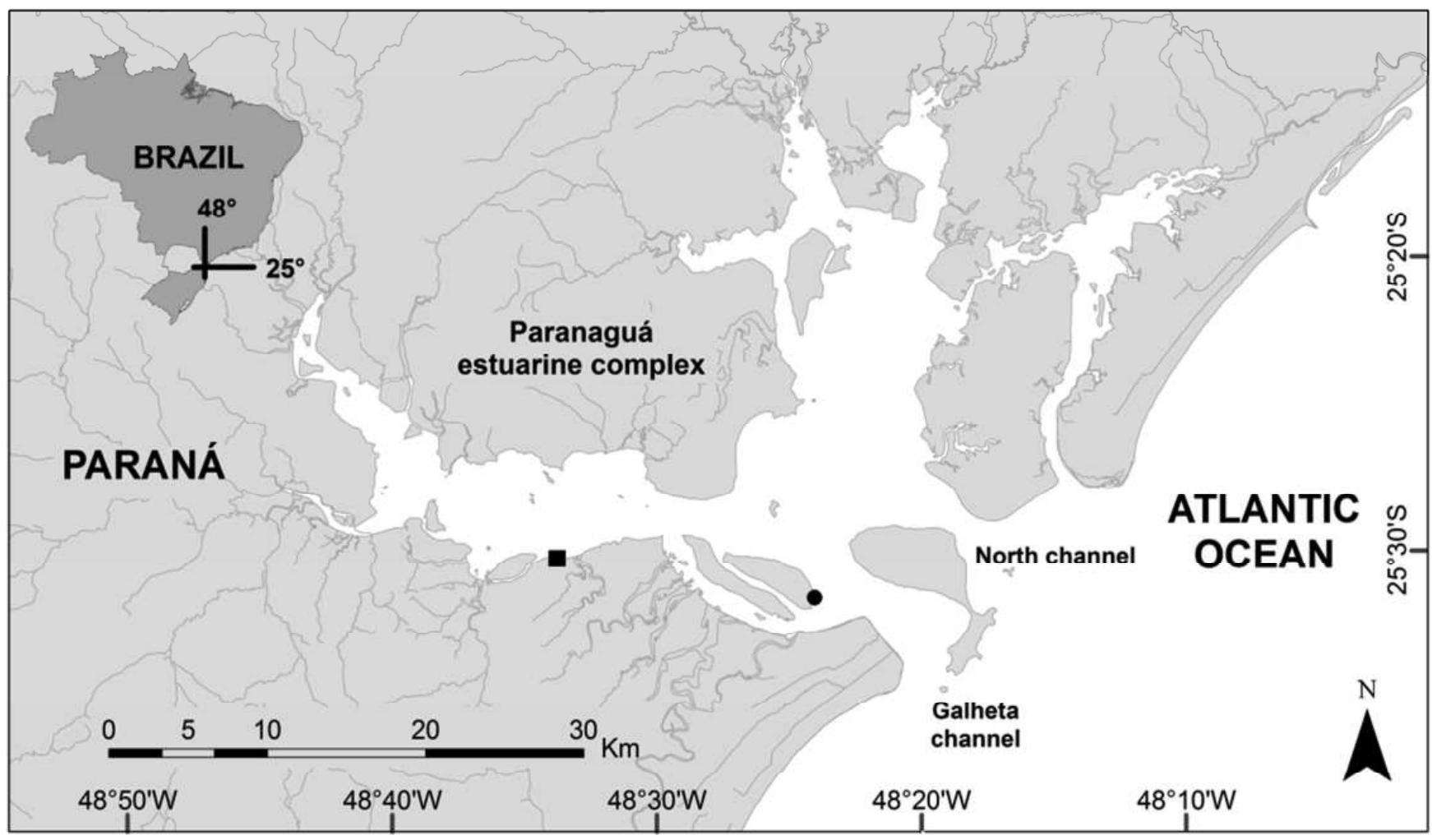

Figure 2 - Temporal distribution of absolute frequency of juveniles the Tagelus divisus in the tidal flat of Paranaguá estuarine complex. $\rightarrow-$ : St. I $(\mathrm{N}=32) ;-\square-\cdot$ : St. II $(\mathrm{N}=243)$.

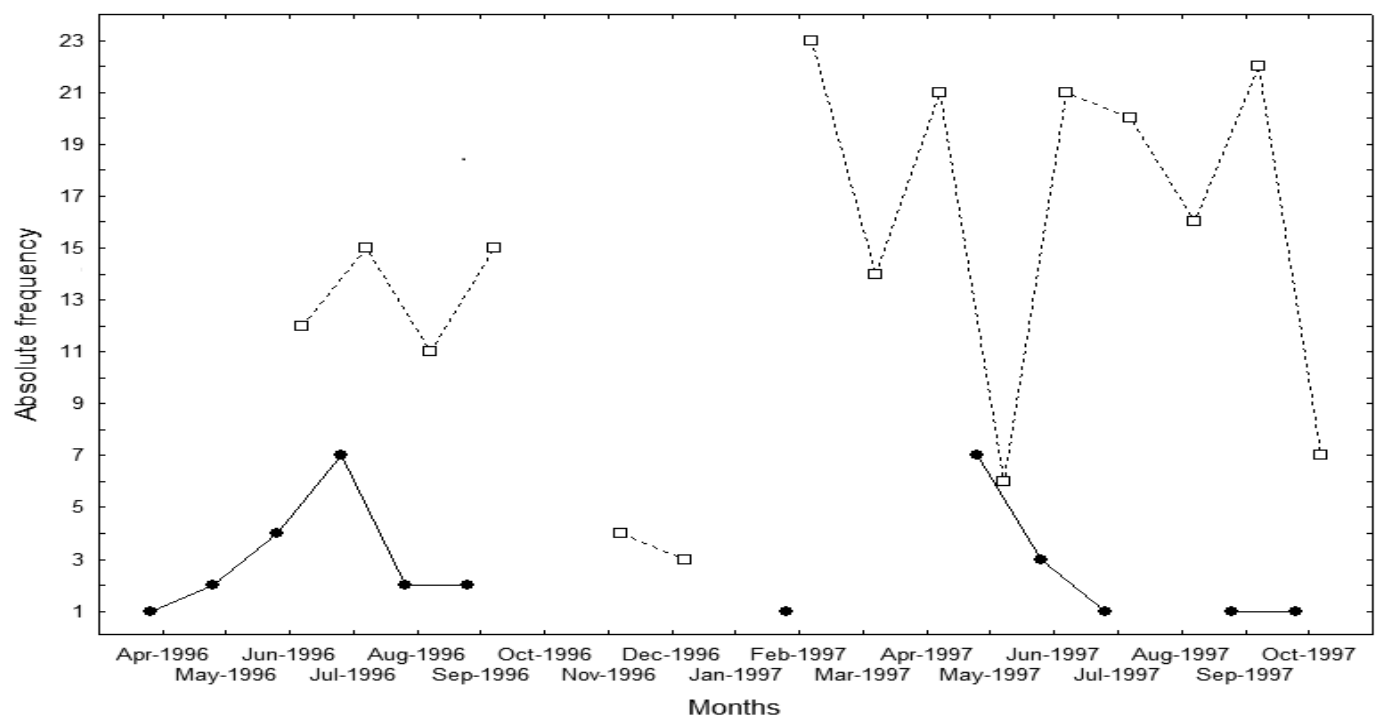


Figure 3 - Spatial variation of juveniles the Tagelus divisus. during the studied period. I: \pm Std. Dev.; $\square: \pm$ Std Err.; $\mathbf{a}$ : Mean.

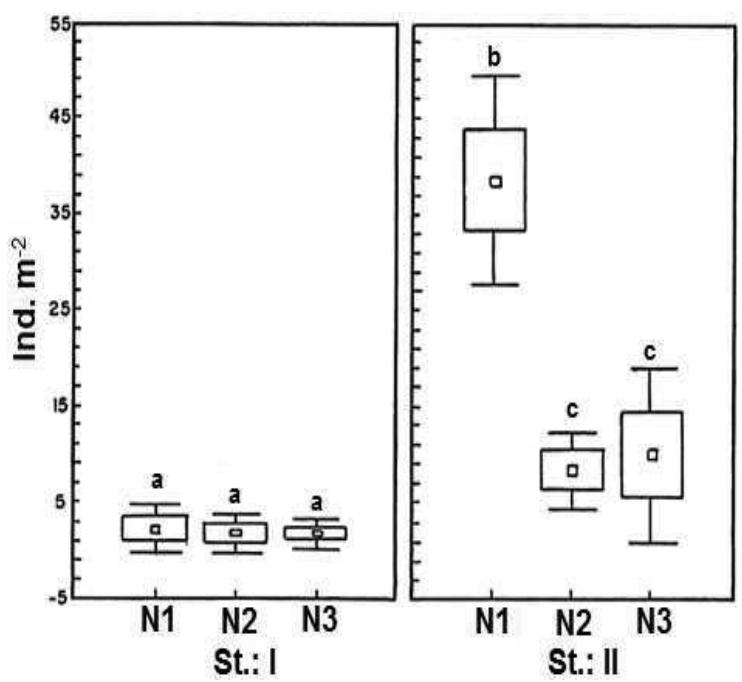

Figure 4 - Seasonal variation of juveniles the Tagelus divisus. during the studied period. 工: \pm Std. Dev.; $\square$ : \pm Std Err.; $\mathbf{a}$ : Mean.

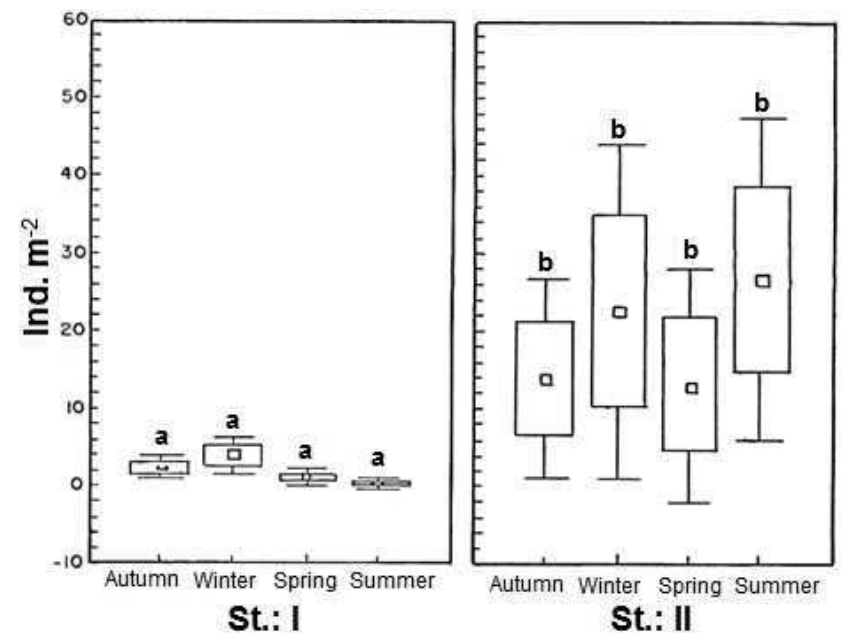

Table 1 - Temporal variation of juveniles classes of Tagelus divisus in the tidal flat of Paranaguá Estuarine Complex. N: number de organisms; L: mean length ( $\mathrm{mm})$; V: variation of size classes of organisms (mm).

\begin{tabular}{|c|c|c|c|c|c|c|}
\hline \multirow{2}{*}{ Months } & \multicolumn{3}{|c|}{ St. I } & \multicolumn{3}{|c|}{ St. II } \\
\hline & $\mathbf{N}$ & L & V & $\mathbf{N}$ & $\mathbf{L}$ & v \\
\hline Apr/1996 & 1 & 16 & 0 & - & - & - \\
\hline May/1996 & 2 & 17 & $15-19$ & - & - & - \\
\hline Jun/1996 & 4 & 10 & $07-11$ & 12 & 7 & $05-21$ \\
\hline Jul/1996 & 7 & 11 & $09-13$ & 15 & 14 & $07-23$ \\
\hline Aug/1996 & 2 & 12 & $11-13$ & 11 & 15 & $01-23$ \\
\hline Sep/1996 & 2 & 15 & $13-17$ & 15 & 17 & $11-23$ \\
\hline Oct/1996 & - & - & - & - & - & - \\
\hline Nov/1996 & - & - & - & 4 & 17 & $15-19$ \\
\hline Dec/1996 & - & - & - & 3 & 7 & $05-09$ \\
\hline Jan/1997 & - & - & - & 33 & 13 & $05-21$ \\
\hline Feb/1997 & 1 & 14 & 0 & 23 & 12 & $05-19$ \\
\hline Mar/1997 & - & - & - & 14 & 12 & $03-19$ \\
\hline Apr/1997 & - & - & - & 21 & 14 & $05-21$ \\
\hline May/1997 & 7 & 9 & $01-15$ & 6 & 15 & $09-19$ \\
\hline Jun/1997 & 3 & 11 & $07-13$ & 21 & 11 & $03-21$ \\
\hline Jul/1997 & 1 & 12 & 0 & 20 & 12 & $07-21$ \\
\hline Aug/1997 & - & - & - & 16 & 16 & $09-21$ \\
\hline Sep/1997 & 1 & 18 & 0 & 22 & 13 & $05-21$ \\
\hline Oct/1997 & 1 & 12 & 0 & 7 & 20 & $19-23$ \\
\hline
\end{tabular}

